Comparative Philosophy Volume 12, No. 1 (2021): 215-221

Open Access / ISSN 2151-6014 / www.comparativephilosophy.org

https://doi.org/10.31979/2151-6014(2021).120117

\title{
RECENT WORK
}

\section{BOOK REVIEW ON \\ MARXISM, CHINA AND GLOBALIZATION \\ (BY XU CHANGFU)*}

\section{IAN HUNT}

Xu Changfu's book is an excellent and thoughtfully written collection of essays on the role that Marxism plays in Chinese thought today and how China fits into the modern world, and raises several interesting problems concerning the role of Marxism in China. $\mathrm{He}$ argues that a freer discussion of Marxism would enable a thoroughgoing Sinicization of Marxism by ensuring interpretations and developments of Marx's thought are produced in China and not simply borrowed from elsewhere, as they will tend to be so long as the discussion of Marxism relates only to the theory's application to social issues in China. The revised edition includes two additional chapters on the nature of the ruling power in a revolutionary society progressing toward socialism. The first introduces a highly interesting discussion of the difference between Lenin and Kautsky over, firstly, the role of elections in a revolutionary situation in which society could progress toward socialism and, secondly, over the nature of "the dictatorship of the proletariat." The second looks at the political legacy of Deng Xiaoping and argues for the importance of rules limiting leadership positions to two terms in the ruling bodies of the People's Republic of China. This review concludes that $\mathrm{Xu}$ raises important issues concerning the understanding of Marxism, and the influence of Marxism in China, which should be widely discussed, given their interest and importance in the world today.

\section{INTRODUCTION: THE RECEPTION OF MARXISM WITHIN CHINA}

$\mathrm{Xu}$ Changfu's book starts with a highly interesting discussion of how Marxism is understood in China today. It takes Marxism, first, as an ideology of the Chinese

HUNT, IAN: Formerly Professor of Philosophy, Flinders University, Australia. Email: ianehunt21@gmail.com

* XU Changfu (2019), Marxism, China and Globalization (revised edition) (Berlin: Parodos), xviii+167 pps. ISBN 978-3-938880-84-5 
Communist Party; second, as CCP-approved interpretations of Marx's thought; and third, as those interpretations of Marx's thought which the CCP tolerates. Xu also refers to interpretations of Marx that can only be published outside China due to the Communist Party of China's disapproval, amongst which are some of his own papers and books, including the one reviewed here.

$\mathrm{Xu}$ points out that the ideological position of the CCP has changed over the years. In the years after the 1949 revolution, it took seriously Marx's claim that centralized ownership of the means of production is a crucial "means" for getting to socialism, while at the same time sacrificing some of Marx's "ends," namely the establishment of a society that is primarily aimed at the freedom and all-around development of each individual. From Deng Xiaoping's "opening up" movement on, Xu claims that the CCP began to adopt reforms that increased the liberty and all-around development of individuals but began to abandon the centralization of the means of production in the hands of the state and to allow private ownership along with markets for exchange, thereby abandoning what Marx said were essential "means" to a socialist society.

There is a third alternative between the horns of the dilemma $\mathrm{Xu}$ poses: that the pursuit of Marx's means to socialism comes at the expense of the pursuit of his "ends." Marx thought that the administration of society should be democratically accountable to the people and that the management of enterprises should be accountable to their workers. $\mathrm{Xu}$ points out that political liberalization has lagged behind economic liberalization in China, so that this essential "end" of Marx's has yet to be pursued. If it were, it might open up the possibility of pursing the means of the centralization of the means of production without the sacrifice of the "ends" that Xu attributes to Marx.

$\mathrm{Xu}$ concludes this highly interesting discussion of work concerning Marx's ideas with a survey of certain outstanding achievements in writings tolerated by the CCP. He concludes by pointing to a possible analogy between the religious conflict in Europe between those who took their ideas of Christianity from the teachings of the Roman Catholic Church and those who sought to take their religion directly from the Bible. $\mathrm{Xu}$ wonders whether a similar gap might open up in China between authorized interpretations of Marxism and interpretations that return to Marx, similar to the differences that developed between Soviet Marxism and Western Marxism.

\section{COMPLETING THE SINICIZATION OF MARXISM}

Xu continues his discussion of Chinese Marxism, in one of the most important chapters in this revised edition of his book, with a revised version of a previously published paper in which he urges a more complete transformation of Sinicized Marxism than has so far been achieved within discussions approved by the Chinese Communist Party, based on the fundamental principles of Marxism. In particular, Xu stresses the need for many voices in the discussion of Marx and Marxism, which he hopes will lead to a more complete adoption of a theoretical scientific attitude, along with a more complete grasp of the centrality of the free, all-around development of individuals in Marx's conception of a future society after capitalism. Despite Marx's aphorism that "The philosophers have only interpreted the world, in various ways: the point is to change it" (Marx and Engels 1986, 15), Xu persuasively argues that Marx takes science seriously as a theoretical enterprise independent of special pleading. He then points out that the interpretation of a body of thought such as Marxism can proceed either from a 
theoretical, critical standpoint or from the standpoint of application, where the body of thought is assumed as it stands when applied.

$\mathrm{Xu}$ claims that the Sinicization of Marxism has only ever proceeded from the standpoint of application: "The most important role that Marxism plays in China is to be the ultimate rationale and justification for the Party's practices, though it is to some extent also the gospel of the poor" (Xu 2019, 25). Xu argues that this "de-theorization" of Marxism has come at a huge cost, including a loss of appreciation of Marx's own attitude towards theory.

$\mathrm{Xu}$ then claims that, because the discussion of Marxism has always involved the discussion of political strategies, Marxism's commitment to the development of individual freedom in society with others has also been lost, in a "de-liberalization" of Marxism. He concludes "insofar as freedom or liberation is the spirit of Marxism, the de-liberalization of it is essentially crushing that spirit. This ... is the biggest error of the Sinicization of Marxism (Xu 2019, 31)."

$\mathrm{Xu}$ concedes that Sinicized Marxism has positive achievements that he has not stressed as much as its shortcomings, but defends his stress on the latter, claiming that because its achievements are universally acknowledged, there is less need to discuss them in a book aimed at raising problems in the understanding of Marxism in China. He concedes also that some study of the fundamental principles of Marxism has occurred in recent years in China, and that some studies not fully in line with the historical Sinicization of Marxism have been allowed. Xu urges that these glimmers of a free, theoretical and critical study of Marxism be fully developed in the future, pointing out that Marxism cannot otherwise be fully Sinicized: "If Chinese researchers of Marxism do not independently produce any original theory, there is nothing they can do but follow, translate, interpret, and apply those theories produced by others, and hence they will always be consumers of theories and dance to others' tunes (Xu 2019, 33)." For a fully developed Sinicization of Marxism, Xu suggests a free discussion of Marx's ideas; a theoretical approach unencumbered by practical concerns about what is acceptable to authorities, which is the key to a properly scientific study of capitalist society; and the allowing of diverse theories to compete with one another, in recognition of the as-yet incomplete development of a Marxist science of capitalist society and social development.

\section{A DISCUSSION OF THINKING ABOUT THE FUTURE}

Xu's next essay deals with the way that China's development and future has been seen, first by Marx and Engels and then by Kang Youwei. Xu's main point is that Marx and Kang agree on the difficulty of change and of stepping into a future harmonious society in one bound; Xu urges us not to forget the lessons that can be drawn from failures of attempting to reach forward toward a new society simply through a will to impose change.

The sixth chapter argues that we need to deal with ideologically driven paths of social change, such as the western hegemonic powers' attempt to impose neoliberal ideology on the global market, by using practical wisdom in developing free cooperative action in pursuit of a better world for the vast majority. It begins with a discussion of the interpretation of Aristotle's concept of "phronesis" in Chinese translations and the emergence of discussions of this idea. $\mathrm{Xu}$ criticises the 
disconnection in Aristotle's thought between theoretical wisdom and practical wisdom, although this disconnection reflects the lack of development of science in the ancient Greek world. Practical wisdom for Aristotle could only take the form of rules for guiding practice and rules for cooperation among citizens in Greek society; Aristotle distinguishes such wisdom from universal sciences such as logic and mathematics.

$\mathrm{Xu}$ then criticises past ideological campaigns in China that have made a fetish of theories and applied them without practical wisdom, and with bad outcomes. These campaigns seem to reflect the persistence of feudal ways of thinking in modern China. $\mathrm{Xu}$ concludes by urging that practical wisdom guide responses to neo-liberal globalisation, so as to lessen the growing inequality it has imposed on developing countries, and also responses to China's development, so that "the free development of the individual," in Marx's terms, becomes the condition of social development.

\section{SHOULD THE PEOPLE'S CONSENT BE THE BASIS FOR SERVING THE PEOPLE?-LENIN AND KAUSKY ON SOCIALISM AND DEMOCRACY}

This new chapter in the revised edition of Xu's book looks at the history of the Constituent Assembly in the Russian Revolution and the breach that emerged between Lenin and Kautsky, together with Rosa Luxemburg, from the German Social Democratic Party, on the role of democracy in the transition from capitalism to communism. Xu notes that the first all-Russia election of a Constituent Assembly in early 1918, promised at the fall from power of the Tsar, elected a majority of members of the Socialist Revolutionary Party and only $25 \%$ of members were elected from the Bolsheviks. The electorate was approximately half of the Russian population entitled to vote at the time, so that no party could claim that any party in the constituent assembly was favoured by a majority of Russians entitled to vote. Having earlier called for the Constituent Assembly, the Bolsheviks responded to the inconvenience of being in a minority in the Assembly by abolishing it, claiming that historically the Russian Social Democrats had treated all institutions as means to successful revolution, having no absolute value in themselves. Lenin also urged the Bolshevik faction of the Russian Social Democrats to change its name to the "All-Russian Communist Party", which did not include any now unfortunate reference to democracy. Xu provides a wonderfully detailed discussion of the reasons for Lenin's move and the response from Kautsky and Luxemburg, who objected to the dissolution of the Assembly as a betrayal of the aim announced by Marx and Engels in "The Communist Manifesto" of "winning the battle for democracy" (Marx and Engels 1986a, 126). Xu's thorough research shows that Lenin was only continuing a line within Russian Social Democracy, according to which the need for revolution justifies any means whatever to reach that end. The problem Xu points to is that this attitude makes it all too easy for leaders to argue more or less speciously to have their political liberty override the development of real political liberty for the working class and people, who they claim to serve.

$\mathrm{Xu}$ also points out the ultimate basis of Lenin's belief that the will of actual workers would not represent their real interests, since "all history" shows that workers cannot themselves develop anything other than trade union consciousness, so that socialist ideas had to be brought to them from intellectual members of the bourgeoisie or petty bourgeoisie. The problem with this historical argument is that trade union politics can bring changes to the historical situation of workers, so that they come to have access to 
education and become just as, if not more, capable of deciding what is in their interests, provided they are able to have access to enough information and are not too subject to false propaganda. The flooding of publicly available forms of expression of ideas with false propaganda has since become the main problem faced by members of the working class in deciding what serves their interests best but this problem faces everyone in society, apart from those with access to other sources of information than mass media.

\section{THE LEGACY OF DENG XIAOPING}

$\mathrm{Xu}$ argues that the most outstanding legacy of Deng Xiaoping's period of rule was the successful pursuit of the policy of "reform and opening out", from which he selects the reform of having fixed terms in office for leading cadres in the ruling bodies of China. $\mathrm{Xu}$ proposes that this legacy can be built upon by having the masses more say in the selection of promising leaders. Xu puts the fixed term in office as an important addition to the methods by which power was historically handed over in China, which were abdication, violent seizure of power at potentially great cost and power taken after the incumbent's death. Xu observes that the last was the most common form of transition in power traditionally in China, because it was potentially the most peaceful.

Xu's analysis should, I think, have gone more into the nature of the power being transmitted, since he seems to assume that the nature of transmitted power today is as absolute as it was in imperial China. This might be true in practice but there are other alternatives, where the problem of transmission of power is lessened by limiting the power of the incumbent, so that they can more easily be removed from office, even if this is not what they want. It might also have improved this highly interesting discussion of Deng Xiaoping's legacy, if the significance of other aspects of the program of "reform and opening up" had been discussed, such as the introduction of market relations, decentralization of economic management and opening up. In recent years, it seems that steps have been taken to limit the decentralization of economic management and to limit "opening up", especially in the discussion of ideas. Nevertheless, $\mathrm{Xu}$ raises issues of utmost importance that require much discussion about the nature of power in China and its accountability to the masses. The latter question, of course, raises the same issues as were discussed in the previous chapter on the debate between Lenin and Kautsky over the importance of winning the battle for democracy.

\section{A CHINESE PERSPECTIVE ON GLOBALIZATION}

Although a chapter on the globalization of labor might not seem to cover Marx's sketchy drafts concerning the essence of human life, Xu begins with a highly interesting discussion of why Marx feels that bourgeois "human rights" are merely a privilege of capital under capitalism, while labor becomes a means to the expansion of capital rather than an expression of the capacity of human beings for free collective labor.

$\mathrm{Xu}$ argues that in breaking free of national constraints, globalized capital presupposes globalized labor, while in reality capital's universalization is one-sided, as labor remains national. $\mathrm{Xu}$ sees this as a source of many conflicts between capital-rich and labor-rich nations in the world today, and contrasts the still-incomplete freedom of capital with the barriers raised against migration. 
Xu's argument here has a Hegelian ring to it, especially when he posits that a globalisation of labor is a condition for reversing the control of capital over labor and bringing the means of production under the control of human beings. Whatever merit this idea might have at an abstract level, at a concrete level we find that the globalisation of capital at most merely counteracts the concentration of capital, so that competition between capital formations continues in some markets. Of course, capital strives for a globalisation of labor to increase its control over labor, but labor organisations strive to limit increased competition between workers to maintain wages and limit the control capital has over labor.

While capital seeks out new labor, in concrete circumstances labor cannot move as easily between countries as capital can, since laborers are not just bearers of capacity for labor but also are members of societies who bear their own cultures. Migrant labor can settle in other countries only under specific conditions and in specific circumstances, as Xu observes (Xu 2019, 112).

It is true, as Marx and Engels say via the words of the Moore-Aveling translation of "The Communist Manifesto" into English: "All fixed, fast-frozen relations, with their train of ancient and venerable prejudices and opinions, are swept away, all newformed ones become antiquated before they can ossify. All that is solid melts into air, all that is holy is profaned, and man is at last compelled to face with sober senses his real conditions of life (Marx and Engels 1986a, 111)." While this is the tendency of capital, the global market also extends from globally traded commodities and products to services that offer products in traditional forms to the societies where those traditions are followed. These services can also spread across the world, so that other cultures become more cosmopolitan to varying degrees. Thus the tendency of capital to strip workers of their illusions is countered by the traditions they learn within families and communal life. While Xu thinks that the globalisation of labor to the same degree as that of capital might help reduce conflicts between nations and give new hope to laborers in labor rich - or capital poor - countries, it seems to me that national conflicts will persist under capitalism, and that new hope for workers in lower wage countries will be seen as a threat to workers in higher wage countries so long as these countries remain capitalist, i.e., possess a social system that exploits workers.

\section{PRACTICAL WISDOM}

The book concludes with a discussion of ecological problems created under capitalism, although ecological problems have occurred under non-capitalist command economies of various kinds, even if they were often not recognized as such. The first centralized systems for appropriating surplus in the ancient economies of the Middle East's Fertile Crescent left widespread desertification in their wake. Similar civilizations in central America also collapsed when centrally controlled irrigation systems proved selfundermining.

$\mathrm{Xu}$ discusses the impact of western capitalism on other countries, which has led to similar effects, as can be seen with deforestation in Brazil and elsewhere in the tropics, including Indonesia. Capitalism has had a similar impact in China. The command system introduced after the Chinese revolution also led to unbalanced development, which is only now being addressed in earnest. 
As Xu observes, collective efforts to coordinate production to minimise ecological problems, while also preserving living standards, tend to be disrupted by capitalism's drive for profit. As Xu says (Xu 2019, 159): "The capitalist way to eliminate poverty has shown that in order to increase poor people's income, you need to multiply the income of the rich. Thus, the quantity of increased GDP will always surpass the quantity required to eliminate poverty." Under capitalism, an increase in incomes for the least advantaged intensifies ecological problems. While Rawls's difference principle might seem to justify the inequalities of capitalism, if the least advantaged are advantaged under them, the difference principle is only one requirement of social justice. Since Rawls's theory of justice as a whole rules out as unjust a social system that allows one generation to destroy the life prospects of subsequent generations for its own advantage (see Rawls 2001), capitalism should be regarded as not only ecologically unjust but also socially unjust, under Rawls's theory of justice.

\section{CONCLUSION}

Overall, Xu's book gives an impressive insight into original work in China in the area of political philosophy. I recommend it highly to readers who want to think about Marx's social theories and the work done on them in China today.

\section{REFERENCES}

Marx, Karl and Engels, Friedrich (1986), Selected Works, Volume 1. (Moscow: Progress Publishers).

Marx, Karl and Engels, Friedrich (1986a), Manifesto of the Communist Party, trans. Samuel Moore and Edward Aveling, in Selected Works, Volume 1 (Moscow: Progress Publishers).

Rawls, John (2001), Justice as Fairness: A Restatement, edited by Erin Kelly (Cambridge, MA: Harvard University Press).

Xu, Changfu (2019), Marxism, China and Globalization (the first edition: 2016) (Berlin: Parodos Verlag). 